\title{
BIOSURFACTANT PRODUCTION BY RHODOCOCCUS ERYTHROPOLIS AND ITS APPLICATION TO OIL REMOVAL
}

\section{Graziela Jardim Pacheco, Elisa Mara Prioli Ciapina, Edelvio de Barros Gomes, Nei Pereira Junior*}

Laboratórios de Desenvolvimento de Bioprocessos, Departamento de Engenharia Bioquímica, Universidade Federal do Rio de Janeiro, Faculdade de Química, Centro de Tecnologia, Rio de Janeiro, RJ, Brasil.

Submitted: June 15, 2009; Returned to authors for corrections: January 17, 2010; Approved: March 29, 2010.

\begin{abstract}
The influence of different nutrients on biosurfactant production by Rhodococcus erythropolis was investigated. Increasing the concentration of phosphate buffer from 30 up through $150 \mathrm{mmol} / \mathrm{L}$ stimulated an increase in biosurfactant production, which reached a maximum concentration of $285 \mathrm{mg} / \mathrm{L}$ in shaken flasks. Statistical analysis showed that glycerol, $\mathrm{NaNO}_{3}, \mathrm{MgSO}_{4}$ and yeast extract had significant effects on production. The results were confirmed in a batchwise bioreactor, and semi-growth-associated production was detected. Reduction in the surface tension, which indicates the presence of biosurfactant, reached a value of $38 \mathrm{mN} / \mathrm{m}$ at the end of 35 hours. Use of the produced biosurfactant for washing crude oilcontaminated soil showed that 2 and 4 times the critical micellar concentration (CMC) were able to remove 97 and $99 \%$ of the oil, respectively, after 1 month of impregnation.
\end{abstract}

Key words: Biosurfactant production, oil removal, Rhodococcus erythropolis.

\section{INTRODUCTION}

The term surfactant is an abbreviation of the expression "surface active agents" (8). These compounds have been exhaustively studied, and they are fundamentally distinguished by their amphiphilic and amphipathic characteristics and by their ability to decrease surface and interfacial tensions of liquids. Biosurfactants are surfactants produced by microorganisms, either directly in microbial cell surfaces or by extracellular secretion. As amphiphilic molecules, biosurfactants contain hydrophilic and hydrophobic portions, and their structures are typically composed of one or more classes of compounds, including mycolic acids, glycolipids, polysaccharide-lipid complexes, lipoproteins, lipopeptides, phospholipids, and/or the microbial cell surface itself $(12,23)$.
The main biosurfactant market is the petroleum industry, where they have been incorporated into oil formulations and utilized in petroleum production and bioremediation. The advantages ascribed to biosurfactants include: their biodegradability, their reduced toxicity and the possibility to be produced by renewable raw material (16). These first two advantages make biosurfactants preferable to chemical surfactants, particularly for environmental applications. Consequently, enhanced oil recovery as well as soil bioremediation represents a large market $(2,18,19)$. Due to their hydrophobicity, oil hydrocarbons bind consistently to soil particles. They also form holes in soil that may exclude water and nutrients. The surface area of oil can be increased by adding synthetic or biological surfactants, which increases the mobility and solubility of hydrocarbons and favors microbial

\footnotetext{
*Corresponding Author. Mailing address: Laboratories of Bioprocess Development - Department of Biochemical Engineering Federal University of Rio de Janeiro, School of Chemistry - Center of Technology - Rio de Janeiro - R.J. - Brazil - CEP 21949-900.; E-mail: nei@ eq.ufrj.br
} 
degradation (15).

It has been reported that biosurfactants produced by the bacterial genus Rhodococcus are glycolipids with tensoactive properties (10). The bacterial cell wall of Rhodococcus has a highly organized and complex cell envelope, formed by a 30 to 54 carbon atom-containing peptidoglycan-arabinoglycan skeleton bonded to mycolic acids that represent more than $40 \%$ of the total cell wall. These acids can be found partially free as trehalose dimycolates and monomycolic lipids. Mycolic acids are 2-alkyl-3-hydroxy fatty acids of high molecular mass that are found exclusively in the cell envelope of bacteria belonging to the mycolata taxa, in which Rhodococcus spp. are included (20).

Studies on the kinetics of biosurfactant production and the nutritional requirements of microorganisms can generate important information about microbial metabolism that allows these parameters to be adjusted to meet the needs of biotechnology. Therefore, we investigated the influence of nutritional parameters and culture conditions on biosurfactant production by a strain of Rhodococcus erythropolis, and then we applied this knowledge to the treatment of crude oilcontaminated soil.

\section{MATERIALS AND METHODS}

\section{Microorganism and growth conditions}

Rhodococcus erythropolis ATCC 4277 was obtained from the bacteria collection of the Department of Microbiology, University of São Paulo, Brazil. The inoculum was grown in sterilized medium as described in Ciapina et al.,2006, (4) and the cells were centrifuged $(9000 \mathrm{x} \mathrm{g})$ and used as fresh inoculum for shaken flask and bioreactor experiments.

\section{Shaken flask experiments}

The basal medium used for all experiments contained $\mathrm{NaNO}_{3} 3.4 \mathrm{~g} ; \mathrm{NaCl} 1.0 \mathrm{~g} ; \mathrm{MgSO}_{4} \cdot 7 \mathrm{H}_{2} \mathrm{O} 0.2 \mathrm{~g} ; \mathrm{CaCl}_{2} .2 \mathrm{H}_{2} \mathrm{O}$ $0.02 \mathrm{~g} ; \mathrm{FeCl}_{3} .7 \mathrm{H}_{2} \mathrm{O} 0.01 \mathrm{~g}$ per liter distilled water, $\mathrm{pH}$ 7.0.
Potassium phosphate buffer concentration varied from 30 up to $150 \mathrm{mmol} / \mathrm{L}$ for specific experiments. Glycerol was added as a carbon source to a final concentration of $2 \%(\mathrm{w} / \mathrm{v})$. The medium was sterilized for $15 \mathrm{~min}$ at $121^{\circ} \mathrm{C}$. The experiments were performed at $200 \mathrm{rpm}, 37^{\circ} \mathrm{C}$ for 5 days.

\section{Batch Experiment in Bioreactor}

A bioreactor Biostat ${ }^{\circledR}$ B $2.0 \mathrm{~L}$ model (B. Braun Biotech International, Germany) was run at $37^{\circ} \mathrm{C}$ with a constant dissolved oxygen level at $20 \%$ of saturation in the fermentation medium (maintained by the intensity of the agitation). The $\mathrm{pH}$ was maintained at 7.0 by automatic addition of hydrochloric acid and sodium hydroxide solutions.

\section{Experimental Design}

A $2^{8-4}$ fractional factorial design was used to evaluate biosurfactant production as a function of glycerol, $\mathrm{NaNO}_{3}$, $\mathrm{NaCl}, \mathrm{MgSO}_{4} \cdot 7 \mathrm{H}_{2} \mathrm{O}, \mathrm{FeCl}_{3} \cdot 7 \mathrm{H}_{2} \mathrm{O}, \mathrm{CaCl}_{2} \cdot 2 \mathrm{H}_{2} \mathrm{O}$, yeast extract and a trace element solution, which composition is as follows (in g/L): $\mathrm{ZnSO}_{4} \cdot 7 \mathrm{H}_{2} \mathrm{O}, 11.0 ; \mathrm{MnSO}_{4} \cdot \mathrm{H}_{2} \mathrm{O}, 6.0 ; \mathrm{FeSO}_{4} \cdot 7 \mathrm{H}_{2} \mathrm{O}$, 1.0; $\mathrm{CuSO}_{4} .5 \mathrm{H}_{2} \mathrm{O}, 0.04 ; \mathrm{CoSO}_{4} .7 \mathrm{H}_{2} \mathrm{O}, 0.04 ; \mathrm{H}_{3} \mathrm{BO}_{3}, 0.06 ; \mathrm{KI}$, 0.01; EDTA, 5.0. These independent variables with their real and encoded values are presented in Table 1. Statistical analysis was performed using Statistica Statsoft Version 6.0 (Tulsa, Oklahoma, USA).

Table 1. Variables studied and their levels in the $2^{8-4}$ fractional factorial experimental design.

\begin{tabular}{lccc}
\hline \multirow{2}{*}{ Variables } & $\begin{array}{c}\text { Low } \\
\text { level }\end{array}$ & $\begin{array}{c}\text { Center } \\
\text { point }\end{array}$ & $\begin{array}{c}\text { High } \\
\text { level }\end{array}$ \\
\cline { 2 - 4 } & $\mathbf{- 1}$ & $\mathbf{0}$ & $\mathbf{+ 1}$ \\
\hline Glycerol (g/L) & 10 & 20 & 30 \\
Sodium Nitrate (g/L) & 1 & 3.4 & 5.8 \\
Sodium Chloride (g/L) & 0 & 1 & 2 \\
Magnesium Sulfate (g/L) & 0 & 0.1 & 0.2 \\
Ferric Chloride (g/L) & 0 & 0.01 & 0.02 \\
Calcium Chloride (g/L) & 0 & 0.02 & 0.04 \\
Yeast Extract (g/L) & 0 & 0.1 & 0.2 \\
Trace Elements (mL/L) & 0 & 0.5 & 1 \\
\hline
\end{tabular}




\section{Analytical methods}

Microbial growth was monitored by biomass measurements by means of optical density observations of the cell suspension at $600 \mathrm{~nm}$, followed by normalizing to the dry cell weight from a calibration plot.

Biosurfactant production was estimated by the concentration of polysaccharide. The choice of this method for surfactant quantitative determination was due to the ability of $R$. erythropolis to produce predominantly polysaccharide-class surfactant when glycerol is used as the carbon source. Polysaccharides were obtained by precipitation of the cell-free spent medium with $95 \%$ ethanol (12). After extraction, total sugars were estimated by the phenol-sulfuric method (6).

The emulsifying activity of the polysaccharide previously isolated was estimated by the method of Cooper and Goldenger, 1987 (5). Samples of $2 \mathrm{~mL}$ of cell-free spent medium were precipitated as described previously, and the precipitate was added to $2 \mathrm{~mL}$ of $n$-hexadecane and vortexed for 2 minutes and left to stand for $24 \mathrm{~h}$. The Emulsification Index at $24 \mathrm{~h}\left(\mathrm{EI}_{24}\right)$ was given as a percentage consisting of the height of the emulsified layer ( $\mathrm{mm}$ ) divided by the total height of the liquid column (mm). The surface tension of the cell-free spent medium was measured by Du Nouy type tensiometer (Krüss Tensiometer, K11 model - Germany) utilizing the ring method as recommended by ASTM (1).

Glycerol concentration was analyzed by enzymaticcolorimetric assay using a triglycerides kit (GPO/POD CELM/Brazil). The nitrate concentration was determined colorimetrically by the brucine sulfate method (4).

\section{Washing experiments}

The method for washing crude oil-contaminated soil was from Urum et al, 2003 (21). Four levels of biosurfactant concentration were utilized: equal to the $\mathrm{CMC}$, twice below the $\mathrm{CMC}$, twice above the $\mathrm{CMC}$ and four times above the CMC (0.45 g/L, $0.23 \mathrm{~g} / \mathrm{L}, \quad 0.9 \mathrm{~g} / \mathrm{L}$ and $1.8 \mathrm{~g} / \mathrm{L}$, respectively). Contaminated soil samples were divided into three groups: immediately contaminated, one-month contaminated and twomonth contaminated. Five grams of the contaminated soil was introduced into flasks containing $25 \mathrm{~mL}$ of biosurfactant (precipitated polysaccharide) solution. Flasks were incubated at $30^{\circ} \mathrm{C}, 300 \mathrm{rpm}, 120 \mathrm{~min}(4)$. After $3 \mathrm{~min}$ of decantation, 1 $\mathrm{mL}$ of the supernatant was washed with n-hexane to remove the crude oil extract (21). Absorbance of the n-hexane/crude oil solution was measured at $294 \mathrm{~nm}$ using DU70 Spectrophotometer (Beckman, Germany).

\section{RESULTS AND DISCUSSION}

\section{Effect of phosphate concentration}

The phosphate buffer used to prevent $\mathrm{pH}$ decline had a strong influence on biosurfactant production and cell growth. In this study we varied the concentration of the phosphate buffer $\left(\mathrm{K}_{2} \mathrm{HPO}_{4}: \mathrm{KH}_{2} \mathrm{PO}_{4} 1: 1\right)$ from 30 to $300 \mathrm{mmol} / \mathrm{L}$ and evaluated its effect on fermentation. As shown in Table 2, concentrations equal to or higher than $60 \mathrm{mmol} / \mathrm{L}$ were sufficient to maintain the $\mathrm{pH}$ of the culture medium throughout the experiment. Although higher concentrations yielded more biomass, our results suggest that a phosphate concentration of $300 \mathrm{mmol} / \mathrm{L}$ modifies the surfactant properties of the product, as indicated by reductions in $\mathrm{EI}_{24}$ and increases in surface tension. Higher values of $\mathrm{EI}_{24}$ were obtained when 100 and 150 $\mathrm{mmol} / \mathrm{L}$ phosphate buffer was added to the culture. At these concentrations, surface tension was reduced to 44.8 and 34.3 $\mathrm{mN} / \mathrm{m}$, respectively, comparable with values reported in the literature $(7,17)$.

Table 2. Observed values of $\mathrm{pH}$, cell concentration, $\mathrm{EI}_{24}$ and surface tension (ST) after $5 \mathrm{~d}$ of fermentation of $R$. erythropolis using potassium phosphate varying from 30 to $300 \mathrm{mmol} / \mathrm{L}$

\begin{tabular}{llllll}
\hline & \multicolumn{5}{c}{ Phosphate Concentration (mmol/L) } \\
\cline { 2 - 6 } \multicolumn{1}{r}{ Response } & $\mathbf{3 0}$ & $\mathbf{6 0}$ & $\mathbf{1 0 0}$ & $\mathbf{1 5 0}$ & $\mathbf{3 0 0}$ \\
\hline $\mathrm{pH}$ & $5.3 \pm 0.14$ & $6.6 \pm 0.03$ & $6.6 \pm 0.28$ & $6.8 \pm 0.14$ & $6.8 \pm 0.03$ \\
$\mathrm{Cell} \mathrm{dw}(\mathrm{g} / \mathrm{L})$ & $1.2 \pm 0.35$ & $1.9 \pm 0.43$ & $2.4 \pm 0.45$ & $2.6 \pm 0.53$ & $3.4 \pm 0.28$ \\
$\mathrm{EI}_{24}(\%)$ & $25 \pm 5.7$ & $31 \pm 4.2$ & $36 \pm 8.5$ & $36 \pm 5.6$ & $10 \pm 7.1$ \\
$\mathrm{ST}(\mathrm{mN} / \mathrm{m})$ & $52.0 \pm 4.13$ & $46.5 \pm 5.08$ & $44.8 \pm 3.62$ & $34.3 \pm 3.25$ & $49.6 \pm 5.71$ \\
\hline
\end{tabular}


Figure 1, shows the amount of biosurfactant produced by $R$. erythropolis after five days of fermentation in different concentrations of phosphate buffer. The results demonstrated that increasing the concentration from 30 up through 150 $\mathrm{mmol} / \mathrm{L}$ stimulates biosurfactant production. The maximum productivity was observed at $150 \mathrm{mmol} / \mathrm{L}$, in which $285 \mathrm{mg} / \mathrm{L}$ of biosurfactant was obtained. This was the concentration used in further experiments. This behavior is consistent with studies performed by Kim et al., 1997 (11), who reported a positive influence of phosphate on biosurfactant production by Bacillus subtilis. On the other hand, Bazire et al., 2005 (3) observed that a concentration of $75 \mu \mathrm{mol} / \mathrm{L}$ of phosphate in LPM63 medium inhibits the cell-to-cell signal molecule N-butyryl-Lhomoserine lactone $\left(\mathrm{C}_{4}\right.$-HSL), which is involved in the quorum sensing system indirectly responsible for biosurfactant production in Pseudomonas aeruginosa.

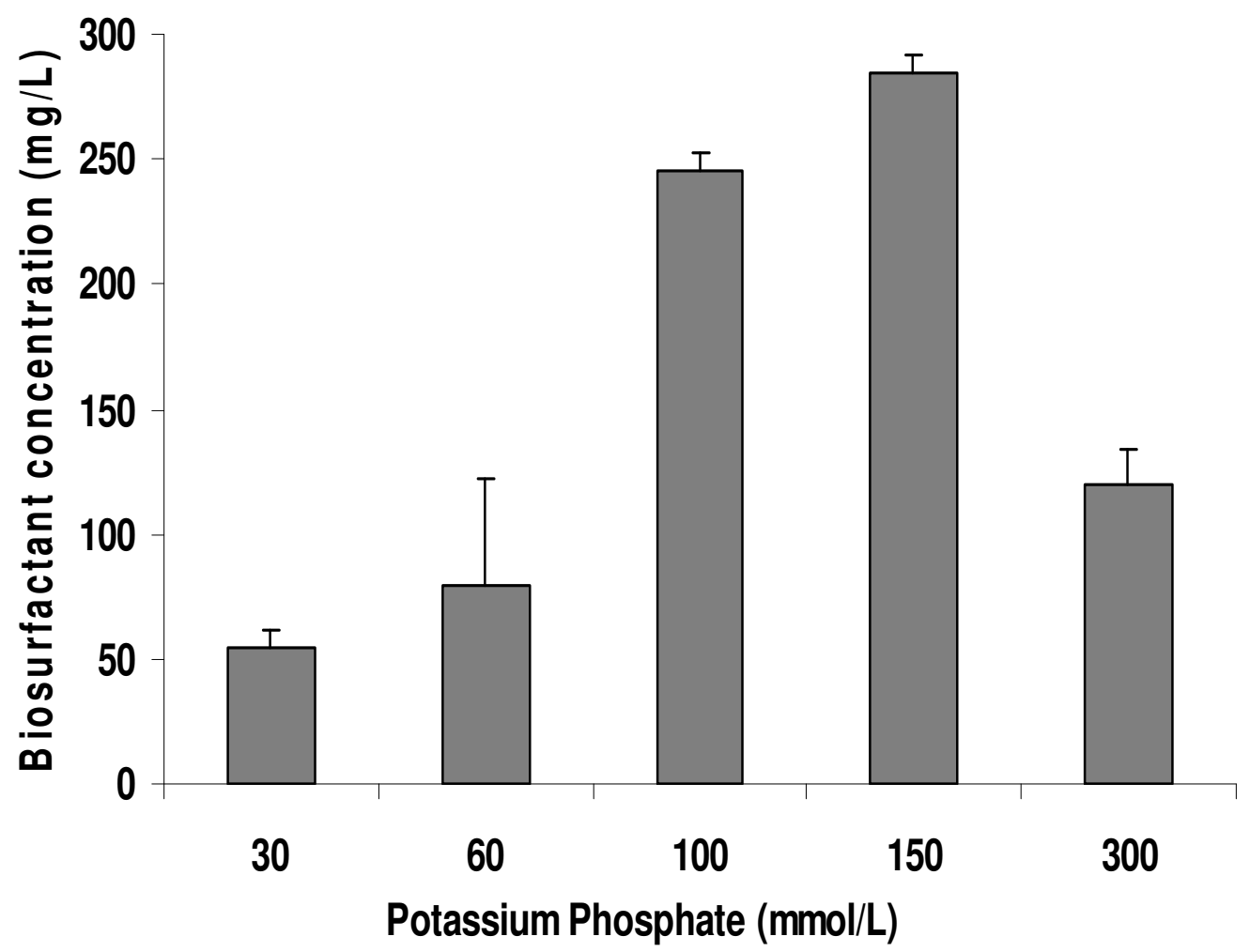

Figure 1. Biosurfactant production by $R$. erythropolis grown in different concentrations of potassium phosphate. Values are expressed as means \pm S.D. $(n=3)$

\section{Effect of different nutrients on biosurfactant production}

The results of the fractional factorial design with four center points are depicted in Table 3. The highest yield factor of product on substrate consumed $\left(\mathrm{Y}_{\mathrm{P} / \mathrm{S}}\right)$ was obtained in essay $5\left(\mathrm{Y}_{\mathrm{P} / \mathrm{S}}=19 \mathrm{mg} / \mathrm{g}\right)$, followed by essay $13\left(\mathrm{Y}_{\mathrm{P} / \mathrm{S}}=14.5 \mathrm{mg} / \mathrm{g}\right)$. It is worthnoting that in both essays the lowest level of glycerol and sodium nitrate and the highest level of yeast extract were used. Additionally, the influence of glycerol, sodium nitrate, and yeast extract on the bioprocess was all statistically significant with values of $p$-level $<0.1$, resulted from the Statistica version 6.0 (Microsoft ${ }^{\circledR}$ ). Therefore, these variables were selected as for identifying the optimum region in the concentration range evaluated (Figure 2). Figure 2 (a) illustrates the combined effect of sodium nitrate and glycerol on the production yield factor $\left(\mathrm{Y}_{\mathrm{P} / \mathrm{S}}\right)$. It is deducible that the influence of $\mathrm{C}: \mathrm{N}$ ratio plays an important role on the 
bioprocess performance. In this case, a $\mathrm{C}: \mathrm{N}$ ratio of $21: 1$ was observed, also considering the presence of $10.5 \%$ total nitrogen in the yeast extract (data not shown). These results suggest that high $\mathrm{C}: \mathrm{N}$ ratios are favorable for the bioprocess, corroborating other reports in the literature, which indicate that the stimulation of biosurfactant synthesis by Rhodococcus sp takes place under nitrogen-limited conditions (11). Concerning the yeast extract, even low concentrations of this complex source of nutrients (0.1-0.2 $\mathrm{g} / \mathrm{L})$ enhanced considerably the bioprocess performance (Table 3 and Figure 2 (b)), pointing out that this complex source of nutrients is necessary since it induces highest production of biosurfactant by $R$. erythropolis.

Table 3. Variables studied (encoded values) and respective response in terms of $\mathrm{Y}_{\mathrm{P} / \mathrm{S}}$ in the $2^{8-4}$ Statistical Fractional Factorial Design

\begin{tabular}{|c|c|c|c|c|c|c|c|c|c|}
\hline Run & Glycerol & $\mathrm{NaNO}_{3}$ & $\mathrm{NaCl}$ & $\mathrm{MgSO}_{4}$ & $\mathrm{FeCl}_{3}$ & $\mathrm{CaCl}_{2}$ & Yeast Extract & Trace Elements & YP/S mg/g \\
\hline 1 & - & - & - & - & - & - & - & - & 9,7 \\
\hline 2 & + & - & - & - & - & + & + & + & 11,5 \\
\hline 3 & - & + & - & - & + & - & + & + & 11,1 \\
\hline 4 & + & + & - & - & + & + & - & - & 5,1 \\
\hline 5 & - & - & + & - & + & + & + & - & 19,0 \\
\hline 6 & + & - & + & - & + & - & - & + & 9,0 \\
\hline 7 & - & + & + & - & - & + & - & + & 8,5 \\
\hline 8 & + & + & + & - & - & - & + & - & 4,3 \\
\hline 9 & - & - & - & + & + & + & - & + & 5,3 \\
\hline 10 & + & - & - & + & + & - & + & - & 3,9 \\
\hline 11 & - & + & - & + & - & + & + & - & 5,1 \\
\hline 12 & + & + & - & + & - & - & - & + & 4,3 \\
\hline 13 & - & - & + & + & - & - & + & + & 14,5 \\
\hline 14 & + & - & + & + & - & + & - & - & 0,8 \\
\hline 15 & - & + & + & + & + & - & - & - & 5,3 \\
\hline 16 & + & + & + & + & + & + & + & + & 2,1 \\
\hline Center point & 0 & 0 & 0 & 0 & 0 & 0 & 0 & 0 & $4,6 \pm 1,3$ \\
\hline
\end{tabular}

Encoded values (-), (0) and (+) represents respectively, low level, center point (intermediate level) and high level for each variable studied. For glycerol, (-), (0) and (+) correspond to $10.0,20.0$ and $30.0 \mathrm{~g} / \mathrm{L}$; for $\mathrm{NaNO}_{3}$ correspond to $1.0,3.4$ and $5.8 \mathrm{~g} / \mathrm{L}$; for $\mathrm{NaCl}$ correspond to $0.0,1.0$ and $2.0 \mathrm{~g} / \mathrm{L}$; for $\mathrm{MgSO}{ }_{4}$ correspond to $0.0,0.1$ and $0.2 \mathrm{~g} / \mathrm{L}$; for $\mathrm{FeCl}_{3}$ correspond to $0.00,0.01$ and $0.02 \mathrm{~g} / \mathrm{L}$; for $\mathrm{CaCl}_{2}$ correspond to $0.00,0.02$ and $0.04 \mathrm{~g} / \mathrm{L}$; for yeast extract correspond to $0.0,0.1$ and $0.2 \mathrm{~g} / \mathrm{L}$; and for trace elements (aqueous solution) correspond to $0.0,0.5$ and $1.0 \mathrm{~mL} / \mathrm{L}$, respectively.

(a)

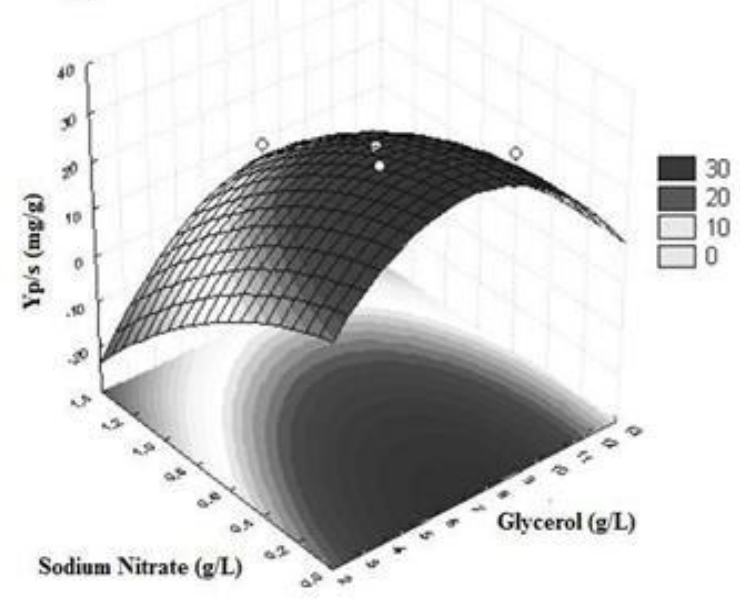

(b)

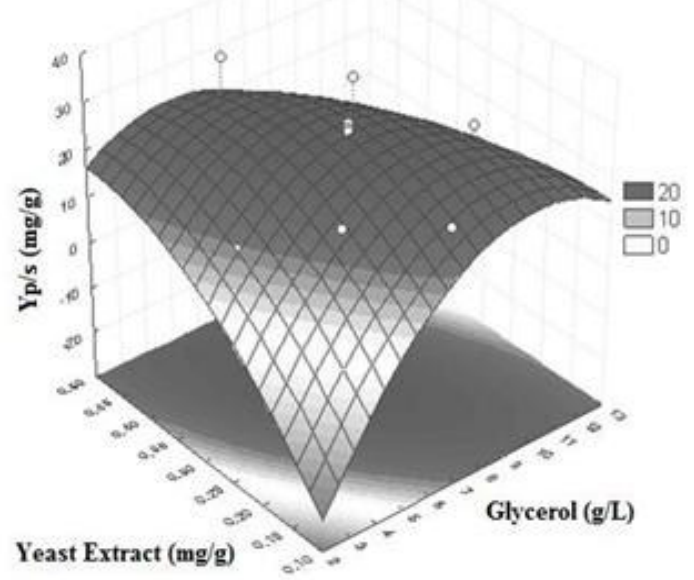

Figure 2. Surface-response graphs generated from the $2^{8-4}$ Statistical Fractional Factorial Design, utilizing $\mathrm{Y}_{\mathrm{P} / \mathrm{S}}$ as a response factor: (a) glycerol and sodium nitrate and (b) glycerol and yeast extract influence on the response factor. 


\section{Bioreactor batch experiment}

In order to validate the results obtained in the factorial experiment, the bioprocess was carried out batchwise in an instrumented bioreactor. This experiment employed concentrations of nutrients considerably more favorable for biosurfactant production.

Figure 3 shows the production of biosurfactant and cell growth in glycerol $(10 \mathrm{~g} / \mathrm{L})$, sodium nitrate (1 g/L), yeast extract $(0.2 \mathrm{~g} / \mathrm{L})$ and potassium phosphate $(150 \mathrm{mmol} / \mathrm{L})$. The exponential growth of $R$. erythropolis started after about 7 hours with a specific growth rate $\left(\square_{\mathrm{x}}\right)$ of $0.035 \mathrm{~h}^{-1}$; which remained constant for approximately 27 hours. Afterwards, the culture entered stationary phase and the glycerol and sodium nitrate ratios in the culture were reduced to $2.9 \mathrm{~g} / \mathrm{L}$ and 0.18 $\mathrm{g} / \mathrm{L}$, respectively. Biosurfactant production started in the early exponential growth phase and continued even after cell growth had ceased, indicating a typical semi-growth-associated mode of production. At the end of the bioprocess, the biosurfactant concentration reached $271 \mathrm{mg} / \mathrm{L}$. The yield factors of biosurfactant per substrate consumed $\left(\mathrm{Y}_{\mathrm{P} / \mathrm{S}}\right)$ and per cells grown $\left(\mathrm{Y}_{\mathrm{P} / \mathrm{X}}\right)$ were $40.2 \mathrm{mg} / \mathrm{g}$ and $301 \mathrm{mg} / \mathrm{g}$, respectively. These obtained parameters surpassed those found in shaken flasks, through experimental design. At the end of the experiment (after 35 hours), the minimum value of surface tension was 38 $\mathrm{mN} / \mathrm{m}$ (data not shown), and an $\mathrm{EI}_{24}$ of $40 \%$ for an $\mathrm{n}$ hexadecane/water binary system was obtained.

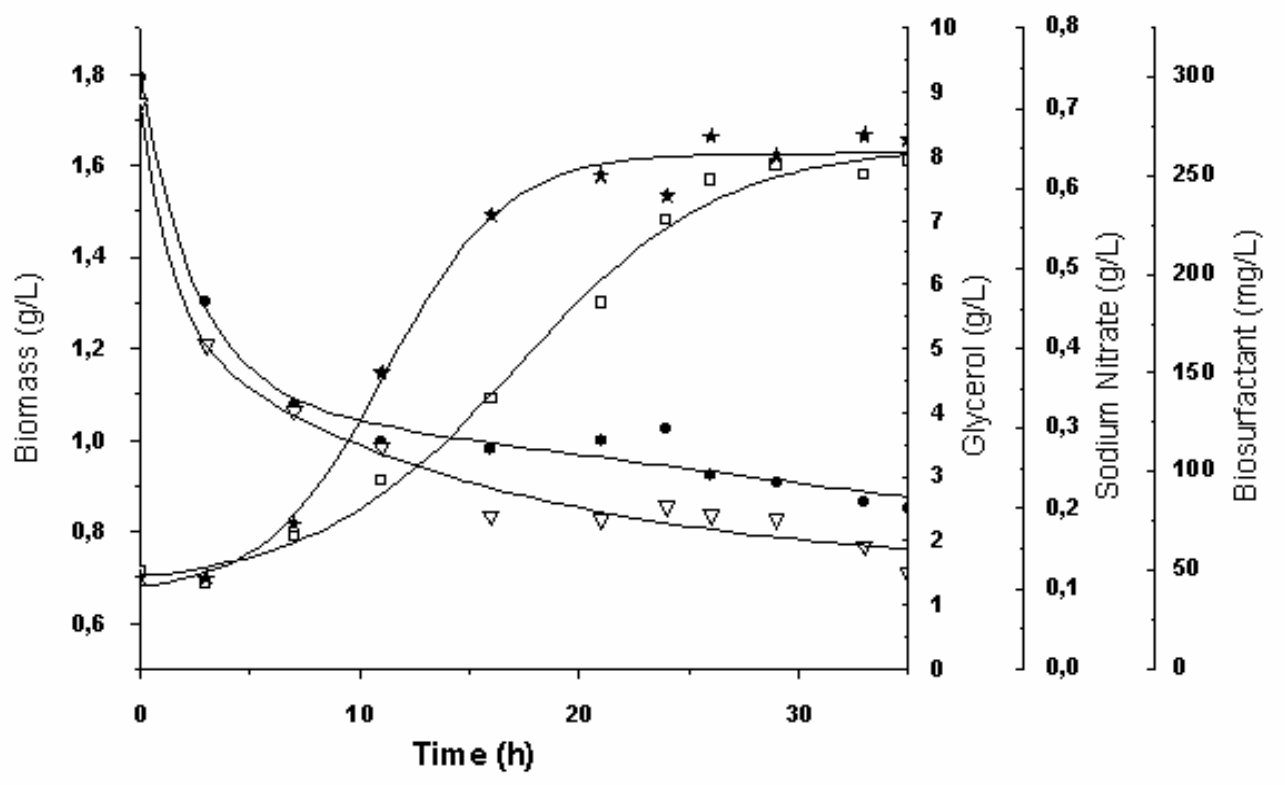

Figure 3. Time-course of growth, biosurfactant production, glycerol and sodium nitrate consumption during cultivation of $R$. erythropolis in a bioreactor ( $\square$ biomass $[\mathrm{g} / \mathrm{L}]$; 7 sodium nitrate $[\mathrm{g} / \mathrm{L}]$; $\bullet$ glycerol $[\mathrm{g} / \mathrm{L}]$; * biosurfactant $[\mathrm{g} / \mathrm{L}]$ ).

\section{Evaluation of the efficiency of the biosurfactant for washing crude oil-contaminated soil}

The emulsifying activity of each concentration used in this experiment is shown in Figure 4. Biosurfactant concentrations of $0.23 \mathrm{~g} / \mathrm{L}, 0.45 \mathrm{~g} / \mathrm{L}$ and $0.9 \mathrm{~g} / \mathrm{L}$ resulted in $\mathrm{EI}_{24}$ values of $27 \%, 40 \%$ and $60 \%$, respectively.

Figure 5 shows the percentage of oil removed from the crude oil-contaminated soil. It is notable that, immediately after soil contamination, the oil-removal efficiency of the biosurfactant was nearly $100 \%$ at all concentrations used. Kuyukina et al., 2005 (13), using biosurfactant produced by Rhodococcus ruber (utilizing n-hexadecane as the carbon source) at twice the CMC observed removal of $80 \%$ of the oil from immediately contaminated soil at $28^{\circ} \mathrm{C}$. 
At $0 \%$ biosurfactant concentration (washing solely with water), the reduction was about $76 \%$ for immediately contaminated soil. However, after a one-month contamination period, the oil-removal ability was considerably reduced, with only $7 \%$ efficiency in the treatment without biosurfactant.

Biosurfactant oil-removal reached maximum efficiency for immediately and 1-month contaminated soils only when 0.9 and $1.8 \mathrm{~g} / \mathrm{L}$ biosurfactant concentrations were applied. These results corroborate those reported by Ivshna et al., 1998 (9), who found that a concentration $2 \mathrm{~g} / \mathrm{L}$ of biosurfactant produced by either Rhodococcus erythropolis or Rhodococcus ruber had the best effect on oil desorption from oil shale.

After a two-month contamination period, the efficiency of oil removal lowers dramatically, with a maximum value of $18 \%$ at the highest concentration of biosurfactant.

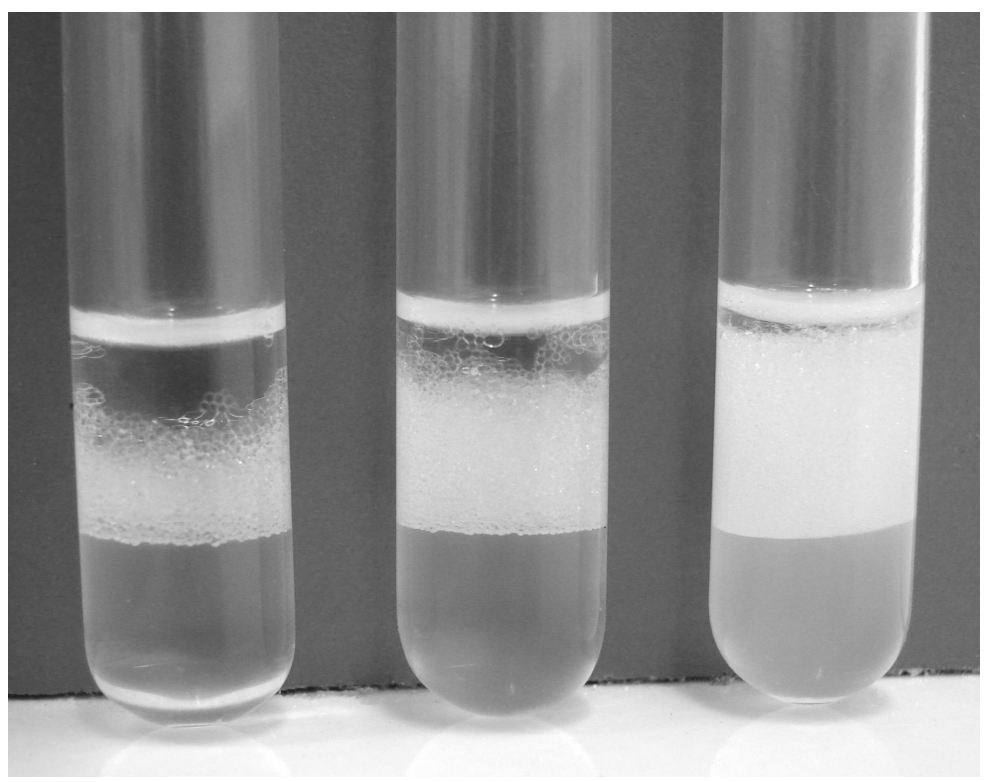

Figure 4. $\mathrm{EI}_{24}$ values obtained from biosurfactant solutions with concentrations twice below the CMC, equal to the CMC and twice above the $\mathrm{CMC}$, from the left to right respectively.

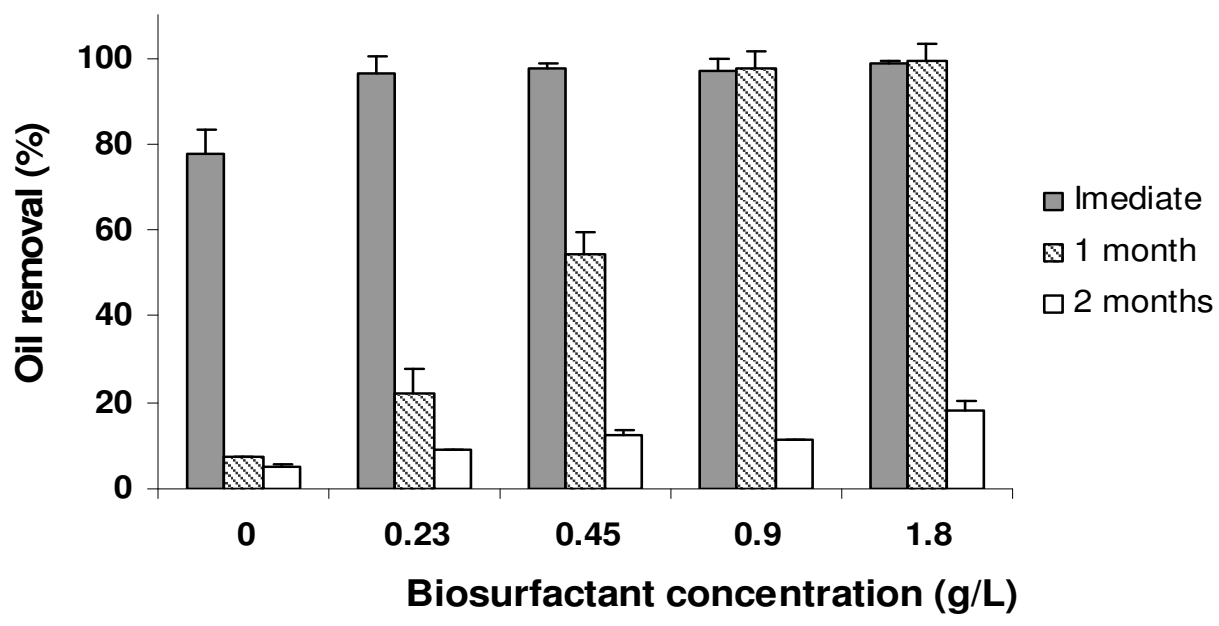

Figure 5. Percentage of oil removed from sandy sediments by different concentrations of biosurfactants, immediately after the contamination and after 1 and 2 months. 
This result suggests that time is a limiting factor for the performance of the biosurfactant, possibly due to greater adsorption of oil to the soil hindering the interaction between the biosurfactant solution and the oil. As the oil remains for longer times, the physical and chemical nature of the soil becomes modified, as noted by Urum et al., 2005 (22). This occurs due to the loss of volatile components and oil of lower molecular weight, resulting in oil with higher density and viscosity. This phenomenon, known as aging (because it is time-dependent), is responsible for the persistence of hydrocarbons in soils because it makes the hydrocarbons less available to microbial and surfactant action. Additionally, as reported by Lee et al., 2002 (14), clay and humus adsorption can reduce the effectiveness of (bio)surfactants for soil remediation, due to the negative charge of clay minerals interacting with the surfactants (positively or negatively charged) and decreasing micelle concentration and the extent of oil solubilization. Conversely, nonionic surfactants are less likely to be adsorbed to the soil.

\section{CONCLUSIONS}

These studies demonstrate that the production of biosurfactant by $R$. erythropolis strain ATCC 4277 can be enhanced by the addition of experimentally defined concentrations of glycerol, sodium nitrate and yeast extract. Phosphate buffer varying from 60 to $150 \mathrm{mmol} / \mathrm{L}$ increases biosurfactant production and also maintain the proper $\mathrm{pH}$ for the fermentation process. Moreover, the results obtained in oilremoval experiments indicate the applicability of biosurfactants to soil bioremediation at low concentrations and at intermediate contamination periods, such as one month.

\section{ACKNOWLEDGEMENTS}

The authors acknowledge the Rio de Janeiro State Foundation for Science and Technology (FAPERJ); the Brazilian Council for Research $(\mathrm{CNPq})$ and the Brazilian Petroleum Company (PETROBRAS) for scholarship and other financial supports.

\section{REFERENCES}

1. ASTM D 971 (1999). $99^{a}$ Standard Test Method for Interfacial Tension of Oil Against Water by the Ring. In: Method American Society for Testing Materials. West Conhohocken, Pennsylvania, USA.

2. Banat, I.M.; Makkar, R.S.; Cameotra, S.S. (2000). Potential commercial applications of microbial surfactants. Appl. Microbiol. Biotechnol. 53(5), 495-508.

3. Bazire, A.; Dheilly, A.; Diab, F.; Morin, D.; Jebbar, M.; Haras, D.; Dufour, A. (2005). Osmotic stress and phosphate limitation alter production of cell-to-cell signal molecules and rhamnolipid biosurfactant by Pseudomonas aeruginosa. FEMS Microbiol. Lett. 253(1), 125-131.

4. Ciapina, E.M.P.; Melo, W.C.; Santa Anna, L.M.M.; Santos, A.S.; Freire, D.M.G.; Pereira Jr, N. (2006). Biosurfactant production by Rhodococcus erythropolis grown on glycerol as sole carbon source. Appl Biochem Biotechnol. 131, 880-886.

5. Cooper, D.G.; Goldenberg, B.G. (1987). Surface active agents from two Bacillus species. Appl. Environ. Microbiol. 53(2):224-229.

6. Dubois, M.; Gilles, K.A.; Hamilton, J.K.; Rebers, P.A.; Smith, F. (1956). Colorimetric method for determination of sugars and related substances. Anal. Chem. 28(3):350-356.

7. Espuny, M.J.; Egido, S.; Rodón, I.; Manresa, A.; Mercandé, M.E. (1996). Nutritional requirements of a biosurfactant producing strain Rhodococcus sp 51T7. Biotechnol. Lett. 18(5), 521-526.

8. Fiechter, A. (1992). Biosurfactants: moving towards industrial application. Trends in Biotechnol. 10(6), 208-217.

9. Ivshina, I.B.; Kuyukina, M.S.; Philp, J.C.; Christofi, N. (1998). Oil desorption from mineral and organic materials using biosurfactant complexes produced by Rhodococcus species. Wrld J. Microbiol. Biotechnol. 14(5), 711-717.

10. Iwabuchi, N.; Sunairi, M.; Urai, M.; Itoh, C.; Anzai, H.; Nakajima, M.; Harayama, S. (2002). Extracellular polysaccharides of Rhodococcus rhodochrous S-2 stimulate the degradation of aromatic components in crude oil by indigenous marine bacteria. Appl. Environ. Microbiol. 68(5), 2337-2343.

11. Kim, H.S.; Yoon, B.D.; Lee, C.H.; Suh, H.H.; Oh, H.M.; Katsuragi, T.; Tani, Y. (1997). Production and properties of a lipopeptide biosurfactant from Bacillus subtilis C9. J. Ferment Bioeng. 84(1), 41-46.

12. Kumar, C.G.; Joo, S.H.; Choi, J.W.; Koo, Y.M.; Chang, C.S. (2004). Purification and characterization of an extracellular polysaccharide from haloakalophilic Bacillus sp. I-450. Enz. Microbial Technol. 34, 673-681.

13. Kuyukina, Maria S.; Ivshina, Irena B.; Makarovb, Sergey O.; Litvinenkob, Ludmila V.; Cunningham, Colin J.; Philp, James C. (2005). Effect of biosurfactants on crude oil desorption and mobilization in a soil system. Env. Int. 31, 155-61.

14. Lee, DH; Cody, RD; Kim, DJ; Choi, S. (2002). Effect of soil texture on 
surfactant based remediation of hydrophobic organic-contaminated soil. Environ. Int. 27, 681-688.

15. Morgan, P.; Watkinson, R.J. (1989). Hydrocarbon degradation in soils and methods for soil biotreatment, CRC Crit. Rev. Biotechnol. 8(4):305333.

16. Mulligan, C.N.; Wang, S. (2006). Remediation of a heavy metal contaminated soil by a rhamnolipid foam. In: Yangt, R.N.; Thomas, H.R., (eds). Geoenvironmental engineering. Integrated management of groundwater and contaminated land. Thomas Telford, London, England, p. 544-551.

17. Philp, J.C.; Kuyukina, M.S.; Ivshina, I.B.; Dunbar, S.A.; Christofi, N.; Lang, S.; Wray, V. (2002). Alkanotrophic Rhodococcus ruber as a biosurfactant producer. Appl. Microbiol. Biotechnol. 59(2-3), 318-324.

18. Renner, R. (1997). European Bans on Surfactant Trigger Transatlantic Debate. Environmental Science Technology. 31(7), 316A - 320A.
19. Scheibenbogen, K.; Zytner, R.G.; LEE, H.; Trevors, J.T. (1994). Enhanced removal of selected hydrocarbons from soil by Pseudomonas aeruginosa UG2 biosurfactants and some chemical surfactants. Journal Chemistry Technology Biotechnology. 59, 53 -59.

20. Sutcliffe, I.C. (1998). Cell envelope composition and organization in the genus Rhodococcus. Antonie van Leeuwenhoek. 74(1-3), 49-58.

21. Urum, K.; Pekdemir, T.; Copur, M. (2003). Optimum conditions for washing of crude oil-contaminated soil with biosurfactant solutions. Trans. I. Chem. 81(3), 203-209.

22. Urum, K.; Grigson, S.; Pekdemir, T.; McMenamy, S. (2005). A comparison of the efficiency of different surfactants for removal of crude oil from contaminated soils. Chemosphere. 62(9), 1403-1410.

23. Van Dyke, M.I.; Lee, H.; Trevors, J.T. (1991). Applications of Microbial Surfactants. Biotech. Adv. 9, 241-252. 